\title{
PENERAPAN ANALYTICAL HIERARCHY PROSESS (AHP) DALAM \\ EVALUASI KONSEP REVITALISASI BANGUNAN CAGAR BUDAYA: STUDI KASUS BANGUNAN GALERI NASIONAL INDONESIA
}

\section{Application of Analytical Hierarchy Process to Evaluate The Concept of Cultural Heritage Revitalization: Case Study Galeri Nasional Indonesia Buildings}

\author{
Jarot Mahendra \\ Galeri Nasional Indonesia \\ Jalan Medan Merdeka Timur No 14 \\ E-mail: jarot_mahendra@yahoo.com \\ Naskah diterima 18 September 2018 - Revisi terakhir 26 Otober 2018 \\ Disetujui terbit 23 November 2018 - Tersedia secara online 30 November 2018
}

\begin{abstract}
This research aims to provide recommendations based on the evaluation of the concept of the revitalization of cultural heritage buildings. Taking the case at the Galeri Nasional Indonesia (GNI), the application of the Analytical Hierarchy Process (AHP) method was used to evaluate the revitalization concept of cultural heritage buildings based on a review of criteria of significance values, identity values, and authenticity values of cultural heritage buildings. AHP applies a quantitative-qualitative evaluation structure with weighted criteria, based on interviews with experts who have backgrounds in archaeology, architecture and fine arts. This study provides results, namely, the value of identity has the highest weight value in the revitalization concept of GNI cultural heritage buildings, followed by the significance value and the last value of the authenticity of cultural heritage buildings. This result recommends that the revitalization concept of cultural heritage buildings in the GNI be reviewed because it can potentially reduce the values contained in cultural heritage buildings.
\end{abstract}

Keywords: AHP, revitalization of cultural heritage buildings, GNI.

\begin{abstract}
Abstrak
Penulisan ini bertujuan untuk memberikan rekomendasi berdasarkan hasil evaluasi terhadap konsep revitalisasi bangunan cagar budaya. Dengan mengambil kasus di Galeri Nasional Indonesia (GNI), metode analytical hierarchy process (AHP) digunakan untuk mengevaluasi konsep revitalisasi bangunan cagar budaya berdasarkan tinjauan kriteria nilai penting, nilai identitas, dan nilai otentisitas bangunan cagar budaya. AHP menerapkan struktur evaluasi kualitatif-kuantitatif dengan kriteria berbobot dan berdasarkan hasil wawancara dengan para ahli (expert) yang memiliki latar belakang di bidang arkeologi, arsitektur, dan seni rupa. Penulisan ini memberikan hasil, yaitu nilai identitas memiliki nilai bobot tertinggi dalam konsep revitalisasi bangunan cagar budaya GNI, disusul nilai penting, dan terakhir nilai otentisitas bangunan cagar budaya. Hasil ini merekomendasikan agar konsep revitalisasi bangunan cagar budaya di GNI ditinjau kembali karena dapat berpotensi terjadinya penurunan nilai-nilai yang terdapat pada bangunan cagar budaya.
\end{abstract}

Kata kunci: AHP, revitalisasi bangunan cagar budaya, GNI.

PENDAHULUAN

Artikel ini memberikan penilaian terhadap konsep revitalisasi bangunan cagar budaya Galeri Nasional Indonesia (GNI) sebagai evaluasi pada rencana revitalisasi bangunan cagar 
budaya di GNI. Alasan utama pentingnya kajian ini adalah bagaimana melakukan evaluasi terhadap suatu konsep revitalisasi bangunan cagar budaya dengan menggabungkan pendekatan kualitatif-kuantitatif melalui metode analytical hieararchy proces (AHP). Umumnya kajian mengenai evaluasi terhadap konsep revitaliasasi bangunan cagar budaya hanya dilakukan dengan pendekatan kualitatif, yaitu berdasarkan persepsi atau sudut pandang ahli dan masyarakat. AHP merupakan salah satu metode yang digunakan dalam bidang kebijakan publik dan mulai sering digunakan dalam bidang pengelolaan cagar budaya. Kajian ini adalah studi pertama yang menerapkan AHP sebagai alat untuk mengevaluasi konsep revitalisasi bangunan cagar budaya. Alasan menggunakan AHP adalah metode ini dapat menggabungkan pendekatan penelitian kualitatif dengan pendekatan kuatitatif sekaligus dalam satu penulisan. Penulisan kualitatif memiliki sifat analisis yang komprehensif, sedangkan penulisan kuantitatif memberikan kemudahan dalam penerapannya. Di sisi lain, metode AHP memberikan pertimbangan untuk menentukan pentingnya setiap kriteria dengan menghitung bobot kriteria dalam hierarki AHP. Besarnya bobot kriteria akan menentukan pengaruh terhadap penilaian keseluruhan.

Pandangan para ahli tentang nilai bangunan cagar budaya dianalisis dengan menggunakan pendekatan AHP. Hal ini memungkinkan mengevaluasi konsep revitalisasi bangunan cagar budaya GNI untuk merekomendasikan apakah konsep ini sudah baik atau perlu dilakukan tinjauan kembali. Suatu keputusan yang kompleks dengan melibatkan berbagai pertimbangan dan pengambilan keputusan menjadi proses yang sulit karena bergantung pada sejumlah faktor yang saling berkaitan. Karena kompleksitas ini, aplikasi expert choice sebagai pendukung pengambilan keputusan semakin banyak digunakan untuk membantu proses ini. Pendekatan analytical hieararchy proces (AHP) yang dikembangkan oleh Saaty dalam Mulyono (2007), adalah salah satu metode pengambilan keputusan yang sering digunakan. Metode matematika yang digunakan pada AHP ini memanfaatkan data yang dikumpulkan melalui teknik kualitatif yang memanfaatkan penilaian dan pengalaman pada ahli (expert) yang terlibat dan mengetahui konsep revitalisasi bangunan cagar budaya GNI.

Artikel ini menggambarkan bagaimana metode AHP dapat diterapkan untuk mengambil keputusan tentang evaluasi konsep revitalisasi bangunan cagar budaya melalui studi kasus rencana pengembangan gedung GNI. Berdasarkan hal ini perlu dicari jawaban atas dua pertanyaan yang penting berikut.

1. Kriteria apa yang perlu diprioritaskan dalam revitalisasi bangunan cagar budaya GNI?

2. Apakah konsep revitalisasi bangunan cagar budaya GNI perlu direvisi? 
TINJAUAN LITERATUR

Revitalisasi Bangunan Cagar Budaya Galeri Nasional Indonesia

Revitalisasi merupakan salah satu upaya dalam pelestarian bangunan cagar budaya dengan menempatkannya sesuai dengan kebutuhan dan fungsi saat ini. Revitalisasi seperti memberikan "kehidupan kedua" pada bangunan cagar budaya dengan cara menghubungkan bangunan cagar budaya dengan kehidupan masyarakat.

Menurut UU No 11/2010, revitalisasi adalah kegiatan pengembangan yang ditujukan untuk menumbuhkan kembali nilai-nilai penting cagar budaya dengan penyesuaian fungsi ruang baru yang tidak bertentangan dengan prinsip pelestarian dan nilai budaya masyarakat. Revitalisasi merupakan salah satu cara pemanfaatan cagar budaya yang bertujuan meningkatkan peran dan nilai cagar budaya melalui penyesuaian fungsi ruang dengan memperhatikan tata ruang, tata letak, fungsi sosial, dan/atau lansekap budaya. Oleh sebab itu, revitalisasi dapat diartikan sebagai proses menata kembali fungsi ruang, nilai budaya, dan penguatan informasi yang disesuaikan dengan fungsi saat ini. Dalam prosesnya revitalisasi bukan hanya bertujuan untuk beautification, tetapi juga untuk memberikan kualitas kehidupan masyarakat yang lebih baik dengan memanfaatkan bangunan lama dan melakukan aktivitas yang berkelanjutan dengan memperhitungkan estimasi ekonomi (Danisworo, 2012).

Revitalisasi bangunan cagar budaya pada kompleks GNI telah menjadi kebutuhan dalam membentuk wajah kebudayaan nasional karena adanya kebutuhan atas galeri nasional yang lebih memadai sebagai galeri yang menggambarkan perkembangan seni Indonesia. Hal ini pun didukung oleh masyarakat, terutama masyarakat seni yang telah lama mendorong bangsa Indonesia yang memiliki kekayaan kebudayaan dari bidang seni untuk memiliki galeri nasional yang berstandar nasional atau internasional.

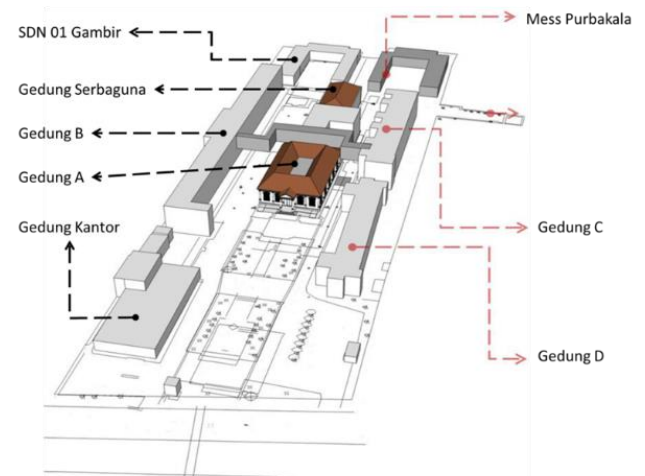

Gambar 1. Bangunan-bangunan yang ada di dalam Kompleks Galeri Nasional Indonesia (Sumber: Sjarief, 2010, telah diolah kembali)

Di dalam kompleks GNI terdapat dua bangunan yang telah ditetapkan sebagai bangunan cagar budaya. Penetapan bangunan itu berdasarkan surat keputusan yang dikeluarkan oleh Gubernur Provinsi DKI Jakarta No. 475 Tahun 1993 tentang Penetapan Bangunan-Bangunan Bersejarah di Daerah Khusus Ibu Kota Jakarta sebagai Benda Cagar Budaya. Kedua bangunan tersebut adalah gedung utama atau Gedung A yang berada di tengah dan gedung serbaguna atau bangsal yang tepat berada di belakang Gedung A. Surat keputusan inilah yang kemudian dijadikan dasar dalam menyusun rencana sayembara masterplan pengembangan GNI dengan 
hanya mempertahankan dua bangunan cagar budaya tersebut.

Konsep revitalisasi bangunan cagar budaya GNI merepresentasikan piramida terbalik, yaitu bagian depan GNI merupakan ruang terbuka yang kemudian menuju ke bagian tengah yang mulai tertutup dan semakin tertutup ke dalam hingga menjadi lebih promitif di bagian belakang. Esensi arsitektur Nusantara dibingkai oleh alam dari zaman kontemporer, masa kolonial, dan pra- kemerdekaan, serta masa prasejarah (Sjarief, 2010). Hal ini mempresentasikan adanya pendekatan pembabakan perjalanan kebudayaan dan sejarah bangsa Indonesia dari masa klasik hingga kebudayaan kontemporer (Gambar 2).

Konsep dimulai dari realita seni yang berasal dari dunia luar (bangunan cagar budaya di sekitar Manumen Nasional) yang kemudian diajak untuk "bertatap muka" dengan seni kontemporer yang merupakan kebudayaan zaman sekarang ketika nilai-nilai modernitas dan tradisional melebur menjadi satu dan saling menghargai. Ajakan ini dibentuk dengan ruang-ruang publik atau plaza dan permainan lansekap yang terintegrasi dengan bangunan-bangunan cagar budaya pada lembaga kebudayaan lain di kawasan Lapangan Merdeka. Area plaza didesain secara fungsional untuk dapat mengakomodasi berbagai kegiatan outdoor, seperti olahraga, diskusi, dan area anak sehingga memungkinkan terdapat aktivitas outdoor yang beragam untuk semua lapisan masyarakat sebagai representasitif Indonesia dengan keragaman budayanya. Selain fungsi, dari segi estetika plaza publik juga merefleksikan keberagaman budaya melalui penataan lansekap yang berpetak, tinggi rendah, dan acak. Penataan yang merefleksikan gairah modernitas dan menggambarkan masa lalu dapat dilihat melalui penataan punden berundak.

Dari desain lansekap, kemudian kita diarahkan untuk menikmati bangunan cagar budaya GNI yang bergaya kolonial asli. Di samping kanan kiri terlihat bangunan galeri yang menyerupai bukit hijau yang mengapit bangunan cagar budaya yang berdiri di tengah-tengah kolam pantul. Kesimetrisan ini menunjukkan bahwa untuk menggali esensi arsitektur Nusantara, harus kembali melihat kekayaan alam Indonesia dengan kepulauan, dataran tinggi, dan lautannya (Sjarief, 2010).

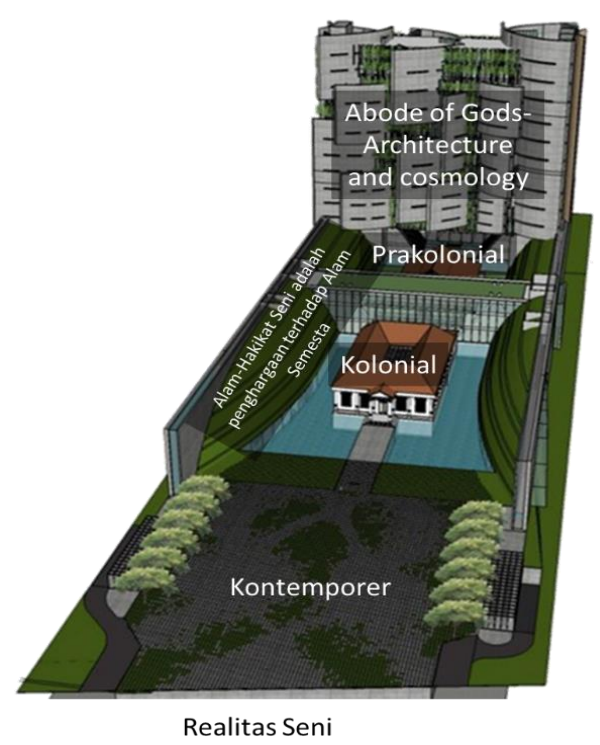

Gambar 2. Konsep revitalisasi bangunan cagar budaya di Galeri Nasional Indonesia berdasarkan hasil sayembara (Sumber: Galeri Nasional Indonesia, 2015, telah diolah kembali) 
Penerapan AHP dalam Penulisan Cagar Budaya

Umumnya penulisan cagar budaya di Indonesia didominasi oleh penulisan yang terfokus pada cagar budaya yang bersifat deskriptif dengan pendekatan kualitatif. Jarang sekali penulisan cagar budaya yang mengkaji pengambilan kebijakan pada pengelolaan cagar budaya. Padahal, kebijakan pengelolaan cagar budaya merupakan ranah yang sangat strategis jika membahas pelestarian cagar budaya. Kajian para arkeolog dan pelestari cagar budaya mengenai nilai penting cagar budaya seolah-olah "tidak berdaya" ketika dibenturkan dengan kebijakan para pengembil keputusan, misalnya kasus pembongkaran Pasar Cinde pada tahun 2017. Tentunya kasus-kasus seperti ini tidak boleh terjadi kembali ketika para pelestari cagar budaya mulai berada dalam wilayah pengambil kebijakan pada pengelolaan cagar budaya.

Sejak AHP mulai dikenal dalam bidang pengambilan keputusan dengan pendekatan yang sistematis, AHP mulai diterapkan dalam berbagai bidang, termasuk pengelolaan cagar budaya. AHP dianggap berhasil dalam memberikan alternatif pilihan pengambilan keputusan dengan mempertimbangkan berbagai aspek atau kriteria. Pendekatan AHP menawarkan sejumlah keuntungan, yaitu dapat menilai seberapa besar pengaruh faktor atau kriteria tertentu dalam pengembilan keputusan, mengurangi subjektivitas dalam pengembilan keputusan, dan melibatkan lebih banyak pemangku kepentingan termasuk masyarakat.
Beberapa penerapan AHP dalam penulisan cagar budaya antara lain sebagai berikut.

1. Penggunaan AHP sebagai metode pengambilan keputusan dilakukan untuk meningkatkan kembali nilai bangunan cagar budaya melalui pemanfaatan bangunan cagar budaya. Dengan mengambil studi kasus Istana the Rocca Estense di wilayah Emilia Romagna, Italia, AHP digunakan untuk menguji prioritas pemanfaatan Istana the Rocca Estanse untuk fungsi baru dan meminimalisasi dampak pada penurunan nilai penting yang terdapat pada bangunan tersebut. Untuk menjawab tujuan tersebut, kriteria AHP yang digunakan ialah shoring work technologies (c.1); historical significance of the building (c.2); unitary of the building (c.3); level of conservation of the building (c.4); interest of the population (c.5); touristic interest (c.6); siteenviroment relationship (c.7); financial sustainability (c.8). Selanjutnya, alternatif yang ditawarkan untuk jenis pemanfaatan bangunan ialah sebagai civic and contemporary exhibition museum (a.1); civic museum and library (a.2); civic and multimedia museum (a.3); civic museum and restaurant (a.4); dan civic museum and literary cafe (a.5). Hasil yang diperoleh adalah pemanfaatan bangunan Istana the Rocca Estense sebagai civic museum and literary cafe (a.5) menjadi prioritas utama. Hasil ini menggambarkan bahwa pengaruh faktor financial sustainability (c.8), 
site-enviroment relationship (c.7), touristic interest (c.6) dan interest of the population (c.5) dalam pemanfaatan Istana the Rocca Estense sangat besar (Morano, Tajani, \& Locurcio, 2016).

2. Penerapan AHP untuk membantu menganalisis hubungan antara pemanfaatan dan konservasi bangunan bersejarah tanpa mengorbankan nilai sejarah dan artistrik bangunan serta mengevaluasi potensi intervensi energi terbarukan untuk merehabilitasi bangunan bersejarah dilakukan oleh Gigliarelli, Cessari, \& Cerqua, (2011) dengan mengambil studi kasus pada Kastil Zena yang terletak di wilayah Emilia Romagna, Italia. Kriteria utama pada model AHP yang menjadi pertimbangan, yaitu sebagai berikut:
a. kajian terhadap
konvensi Internasional (dengan mempertimbangkan aspek reversibility, compatibility, dan minimum intervensi);

b. efektivitas energi dengan memaksimalkan kinerja energi terbarukan yang digunakan agar lebih hemat;

c. environmental sustainability (dengan meminimalkan pencemaran lingkungan);

d. economic feasibility (untuk meminimalkan biaya).

Hasil kajian menemukan masalah yang perlu diprioritaskan, yaitu kompleks arsitektur bangunan yang membutuhkan sistem energi baru karena instalasi energi yang ada kondisinya sangat buruk. Selain itu, dengan instalasi, energi saat ini memiliki daya konsumsi yang tinggi untuk alat pemanas dan pendingin. Kemudian, untuk memecahkan masalah ini disarankan membuat sistem pasokan energi baru dengan menggunakan energi terbarukan dan peningkatan efisensi alat pemanas dan pendingin (Gigliarelli, Cessari, \& Cerqua, 2011).

3. Strategi perencanaan kebijakan konservasi cagar budaya di Cina yang lebih komprehensif dengan mempertimbangkan berbagai aspek. Aspek teknologi dengan subkriteria conservation dan restoration, kemudian aspek nonteknologi dengan subkriteria social consciousness, conservation law, conservation policy, conservation research, professional education, dan economic devotion dijadikan faktor-faktor yang menjadi pertimbangan dalam menyusun strategi konservasi yang komprehensif. Rekomendasi dari penulisan tersebut, penerapan teknologi restorasi cagar budaya perlu segera dilakukan. Penerapan ini perlu didukung oleh landasan hukum yang terintegrasi dengan peraturan yang ada, kebijakan bantuan keuangan, kebijakan pembangunan sosial, ekonomi, pendidikan, dan penulisan (Yaolin, 2006).

\section{METODE}

Analytical hierarchy process (AHP) merupakan pendekatan dalam pengambilan keputusan dengan banyak kriteria secara sistematis. AHP 
dikenalkan pertama kali oleh Thomas L. Saaty pada periode 1971 - 1975 (Mulyono, 2007). AHP menawarkan penyelesaian masalah yang melibatkan sumber kerumitan yang mengandalkan intuisi atau persepsi manusia sebagai input utamanya, tetapi intuisi atau persepsi itu harus datang dari seorang ahli yang memiliki informasi dan memahami masalah yang dihadapi dengan mengunakan konsep hierarki (Mulyono, 2007). Karena AHP menggunakan input persepsi manusia (hal yang bersifat kualitatif), model ini dapat mengolah hal-hal yang bersifat kualitatif dengan menggunakan logika kuantitatif. Kelebihan model AHP jika dibandingkan dengan model penulisan kuantitatif lainnya terletak pada kemampuannya untuk memecahkan masalah yang multiobjective dan multicriteria, karena memiliki fleksibilitas yang tinggi, terutama dalam pembuatan hierarki. Sifat fleksibilitas tersebut membuat model AHP dapat menangkap beberapa tujuan dan beberapa kriteria sekaligus dalam sebuah model atau hierarki (Brodjonegoro, 1992).

Hierarki merupakan alat yang paling mudah untuk memahami masalah yang kompleks, yaitu masalah tersebut diuraikan ke dalam elemenelemen yang terkait dan menyusun elemen-elemen secara hierarkis (Brodjonegoro, 1992).

Dalam penulisan ini konsep revitalisasi bangunan cagar budaya dijadikan sebagai goal yang akan diuji melalui AHP. Goal adalah masalah yang akan dicari pemecahannya lewat model AHP. Goal ini bermaksudkan untuk mengevaluasi konsep revitalisasi bangunan cagar budaya GNI perlu atau tidaknya untuk direvisi. Penulisan ini mengunakan kriteria utama berupa nilai-nilai yang berpengaruh dalam revitalisasi bangunan cagar budaya, yaitu sebagai berikut.

1. Nilai Penting adalah nilai-nilai yang dimiliki bangunan cagar budaya sebagai parameter dalam pelestarian cagar budaya.

2. Identitas adalah suatu dimensi penting dalam kehidupan sosial dan budaya yang melibatkan ingatan bersama tentang masa lalu dan sangat berkaitan dengan keterikatan, serta feeling memiliki dan makna bagi masyarakat (Gospodini, n.d.; Kaymaz, 2013).

3. Otentisitas adalah penilaian tentang nilai keaslian yang dikaitkan dengan sifat bangunan cagar budaya, konteks budaya, dan perkembangannya.

Kriteria utama tersebut dipilih berdasarkan observasi bahwa rencana revitalisasi bangunan cagar budaya di GNI saat ini (Gambar 2) tampak adanya beberapa perubahan atau intervensi fisik pada bangunan cagar budaya dan bangunan lain yang berada di sekitarnya. Intervansi pada bangunan cagar budaya (Gedung A) terlihat adanya upaya untuk mengembalikan bentuk (fasad) bangunan ke masa awal dibuatnya bangunan ini berdasarkan arsip sejarah yang ada setalah mengalami proses budaya. Selain itu, perubahan pada bangunan-bangunan di sekitarnya, yaitu adanya rencana penghapusan beberapa bangunan, terutama Gedung B, yang walaupun belum ditetapkan sebagai bangunan 
cagar budaya, mungkin saja masuk dalam kriteria bangunan yang diduga cagar budaya menurut UU No.11/2010 karena secara kriteria usia bangunan telah lebih dari lima puluh tahun dan memiliki konteks sejarah yang sama dengan bangunan cagar budaya (Gedung A) saat kompleks ini difungsikan sebagai sekolah.

Selain itu, ketiga kriteria tersebut diambil juga dengan pertimbangan bahwa dalam konsep revitalisasi bangunan cagar budaya di GNI, minimal bangunan tersebut harus dapat memuat ketiga hal ini, sehingga konsep tersebut dapat mencapai tujuan pelestarian yang telah diamanahkan dalam UU No 11/2010.

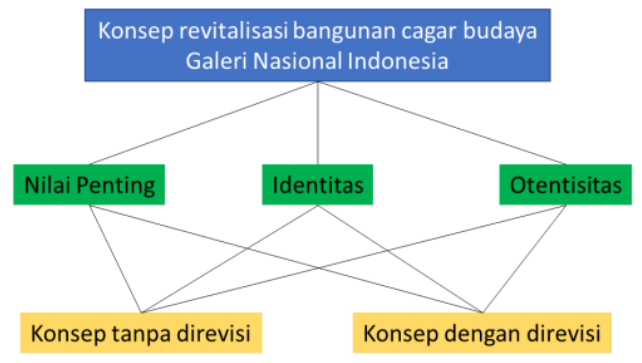

Gambar 3. Heirarki AHP dalam penulisan ini

Model AHP ini dipilih karena dapat mengevaluasi konsep revitalisasi bangunan cagar budaya dengan beberapa kriteria sekaligus berdasarkan persepsi atau sudut pandang expert.

Model AHP menggunakan batas rasio 1 sampai dengan 9 yang dianggap cukup mewakili persepsi manusia (Brodjonegoro, 1992). Dengan memakai skala rasio 1 sampai dengan 9, para responden model AHP dapat menyatakan persepsinya dengan memperbandingkan dua buah elemen atau lebih. Skala pernbandingan berpasangan dalam model AHP dijelaskan pada tabel 1 .

Tabel 1. Skala Perbandingan Berpasanagan (Scale for Pairwise Comparison)

\begin{tabular}{cl}
\hline Skor & \multicolumn{1}{c}{ Definisi } \\
\hline 1 & $\begin{array}{l}\text { Sama Penting } \\
\text { importance) }\end{array}$ \\
3 & $\begin{array}{l}\text { Sedikit lebih penting (Moderate } \\
\text { importance of one over another) }\end{array}$ \\
5 & $\begin{array}{l}\text { Agak lebih penting (Strong or } \\
\text { essential importance) }\end{array}$ \\
7 & $\begin{array}{l}\text { Jauh lebih penting (Very strong } \\
\text { or demonstrated importance) }\end{array}$ \\
9 & $\begin{array}{l}\text { Mutlak lebih penting (Extreme } \\
\text { importance) }\end{array}$ \\
2,4, & $\begin{array}{l}\text { Nilai antara di atas (Intermediate } \\
\text { values) }\end{array}$ \\
\hline Sumb
\end{tabular}

Sumber: Brodjonegoro (1992)

Salah satu asumsi utama model AHP yang membedakan dengan modelmodel lain adalah tidak adanya syarat konsistensi mutlak. Hal ini didasari oleh kerap munculnya ketidakkonsistenan dalam kejadian-kejadian yang bersifat noneksak atau tidak banyak berdasarkan logika (Brodjonegoro, 1992). Persepsi manusia sebagian didasari oleh logika dan sebagian lagi didasarkan pada unsur-unsur bukan logika, seperti perasaaan, pengalaman, intuisi sehingga sepantasnyalah model AHP tidak menuntut syarat konsistensi 100\% secara mutlak.

Pengukuran konsistensi dalam model AHP dilakukan dalam dua tahap. Tahap pertama adalah mengukur konsistensi setiap matriks perbandingan dan tahap kedua adalah mengukur konsistensi secara keseluruhan hierarki. Dalam model AHP, pengukuran konsistensi dari suatu matriks didasarkan atas suatu eigenvalue maksimum dengan rumus indeks 
inkonsistensi sebagai berikut:

$$
\mathrm{IK}=\frac{(\lambda \text { maks }-n)}{n-1}
$$

Keterangan

IK : indeks inkonsistensi

n : matriks

$\lambda$ maks : eigenvalue ( $\lambda$ maks $\geq n)$

Indeks inkonsistensi

tersebut kemudian diubah ke dalam bentuk rasio inkonsisten (RK), yaitu membaginya dengan indeks random (IR), yang dituliskan dengan persamaan berikut:

Keterangan

$$
\mathrm{RK}=\frac{\mathrm{IK}}{\mathrm{IR}}
$$

RK : rasio konsistensi

IK : indeks konsistensi

IR : indeks random

Berdasarkan hasil penulisan Oak

Ridge National Laboratory yang dilanjutkan oleh Wharton School, apabila tingkat inkonsistensi lebih kecil dari $10 \%$, tingkat inkonsistensi masih dapat diterima. Sebaliknya, apabila nilai tingkat inkonsistensi lebih besar dari $10 \%$, harus adanya revisi penilaian karena tingkat inkonsistensi yang terlalu besar dapat menjurus pada suatu kesalahan (Brodjonegoro, 1992).

\section{Prosedur}

Wawancara expert dalam kajian ini terbagi menjadi dua bagian, yaitu pada bagian pertama untuk mendapatkan data kualitatif sebagai input utama yang berupa persepsi atau intuisi dari expert. Selanjutnya, bagian kedua digunakan untuk memperoleh data kauntitatif dengan menggunakan kuesioner AHP.
Bagian pertama adalah
wawancara mendalam (in-depth
interview) yang dilakukan untuk
memperoleh informasi yang lebih
banyak dan mendalam dari expert
dalam evaluasi revitalisasi bangunan
cagar budaya berdasarkan kirteria AHP. Expert diberi pertanyaan-pertanyaan terbuka mengenai kriteria yang telah dipilih, yaitu nilai penting, identitas, dan otentisitas bangunan cagar budaya. Pada bagian ini expert diberikan kebebasan merespons pertanyaan yang diajukan sehingga data yang diterima dapat beragam dan memberikan kekayaan data yang informatif dalam evaluasi konsep revitalisasi bangunan cagar budaya GNI.

Pada bagian kedua pertanyaan yang diajukan bersifat tertutup dengan menggunakan kuesioner AHP. Sebelum memberikan pertanyaan yang ada pada kuesioner, terlebih dahulu dijelaskan goal, hierarki, definisi istilah, serta cara pengisian kuesioner AHP. Dalam pengisiannya, expert dapat mengisi langsung kuesioner AHP oleh dirinya sendiri atau dibantu pada saat pengisian kuesioner berdasarkan jawaban yang diberikan. Setelah pengisian kuesioner selesai dilakukan kaji ulang (review) pertanyaan dan jawaban expert pada kuesioner serta mempersilahkan expert untuk memeriksa kembali jawaban pada kuesioner. Selanjutnya, ketika expert telah menyetujui jawabannya, peneliti mempersilakan expert untuk membubuhkan tanda tangan pada kuesioner sebagai sebuah persetujuan atas jawaban pada kuesioner. Hal ini dilakukan untuk menjaga validasi data kuantitaif pada kuesioner. 


\section{Penentuan Expert}

Dalam penulisan ini, terminologi expert mengalami perbedaan antara terminologi expert dalam wawancara kualitatif dan terminologi expert untuk mendapatkan data kuantitatif. Kriteria expert dalam wawancara kualitatif adalah seseorang yang dengan pengetahuan, pengalaman, dan keahliannya dapat memberikan interpretasi mengenai--tema yang diangkat atau dapat memberikan informasi yang komprehensif mengenai data yang diperlukan dalam penulisan ini.

Expert dalam wawancara kualitatif dipilih berdasarkan keahliannya di bidang ilmu arkeologi, ilmu arsitektur dan ilmu seni rupa. Ketiga bidang keahlian ini dipilih karena dalam revitalisasi bangunan cagar budaya di GNI berkaitan dengan bangunan cagar budaya yang berada dalam ranah ilmu arkeologi, bangunan gedung sebagai sebuah karya arsitektur, dan fungsi bangunan GNI sebagai pusat aktivitas seni, khususnya seni rupa.

Selanjutnya, dianalisis data kuantitatif dengan model AHP. Kriteria expert bukan berarti bahwa orang tersebut haruslah genius, pintar, bergelar doktor, dan sebagainya, melainkan mengacu pada orang yang mengerti benar permasalahan yang diaijukan, merasakan akibat suatu masalah, atau mempunyi kepentingan terhadap masalah tersebut (Brodjonegoro, 1992).

Berdasarkan kriteria expert tersebut, pemilihan expert untuk meninjau kebijakan revitalisasi bangunan cagar budaya di GNI dapat berdasarkan kepentingan dalam pelaksanaannya, yaitu goverment interests, public interests, dan economic interests (The Hong Kong Institute of Architect, 2012). Goverment interests diwakili oleh pejabat pada institusi Galeri Nasional Indonesia, Tim Ahli Cagar Budaya (TACB), dan Tim Sidang Pemugaran Provinsi (TSP) DKI Jakarta. Public interests diwakili oleh masyarakat dari kalangan arkeolog, arsitek, dan seniman. Namun, economic interests tidak termasuk dalam kajian. Penulisan ini difokuskan pada konsep revitalisasi bangunan cagar budaya. Oleh sebab itu, tidak ada expert yang mewakili untuk economic interests.

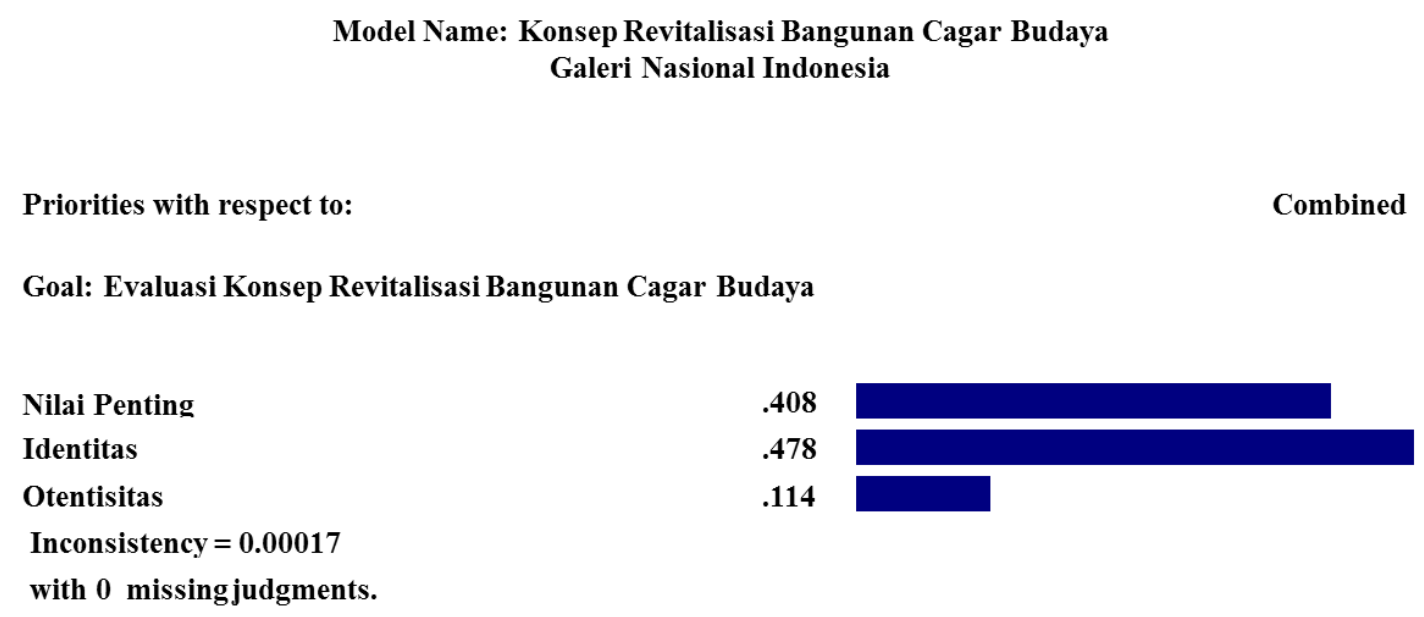

Gambar 4. Hasil pembobotan AHP Antarkriteria Utama (Sumber: Jarot Mahendra, 2018) 
HASIL DAN PEMBAHASAN Hasil Pembobotan Antarkriteria

Hasil analisis dengan metode AHP memberikan gambaran mengenai evaluasi konsep revitalisasi bangunan cagar budaya GNI. Evaluasi dilakukan berdasarkan kriteria utama yang telah ditentukan dalam evaluasi revitalisasi bangunan cagar budaya ini (Gambar 4).

Berdasarkan Gambar 4, dapat terlihat bahwa kriteria identitas merupakan kriteria yang paling memengaruhi revitalisasi bangunan cagar budaya GNI dengan bobot sebesar 47,80\%. Hasil ini menggambarkan bahwa dalam melakukan revitaslisasi bangunan cagar budaya harus dipertimbangkan nilai identitas. Hal ini penting karena identitas dapat memengaruhi semua pemangku kepentingan, termasuk masyarakat untuk peduli terhadap pelestarian bangunan cagar budaya. Nilai identitas dapat dinarasikan dalam konteks masa kini agar masyarakat saat ini merasakan kehadirannya sebagai bagian dari bangunan cagar budaya.

Terlebih bagi negara-negara terjajah seperti Indonesia, yang dihadapi adalah bangunan-bangunan bersejarah peninggalan bangsa penjajah atau kolonialisme. Oleh karena itu, perlu dilakukan suatu sikap untuk mencari identitas bangsa yang tidak menutup kemungkinan identitas itu didapat dari peninggalan kolonialisme tersebut. Namun, tidak berarti dalam pencarian identitas itu, kita terjebak pada romantisme sejarah masa lalu yang kurang mengenakan sehingga mengurangi nilai identitas bagi kehidupan masyarakat dan bangsa.
Oleh karena peran penting nilai identitas dalam bangunan cagar budaya dalam Undang-Undang Nomor 11 Tahun 2010, nilai identitas menjadi salah satu kriteria penting yang harus dipenuhi dalam penetapan cagar budaya. Kriteria tersebut termuat dalam Undang-Undang Nomor 11 Tahun 2010 Pasal 5 sebagai berikut.

Benda, bangunan, atau struktur dapat diusulkan sebagai benda cagar budaya, bangunan cagar budaya, atau struktur cagar budaya apabila memenuhi kriteria:

a. berusia 50 (lima puluh) tahun atau lebih;

b. mewakili masa gaya, paling singkat berusia 50 (lima puluh) tahun;

c. memiliki arti khusus bagi sejarah, ilmu pengetahuan, pendidikan, agama, dan/atau kebudayaan; dan

d. memiliki nilai budaya bagi

penguatan kepribadian bangsa.

Penggunaan kata dan (kata yang dicetak tebal) pada pasal ini, memberi arti bahwa bangunan dapat ditetapkan sebagai bangunan cagar budaya jika telah memenuhi keempat kriteria tersebut. Salah satu kriteria (butir d) menyatakan bahwa bangunan yang akan ditetapkan sebagai bangunan cagar budaya harus memiliki nilai budaya bagi penguatan kepribadian bangsa, dengan kata lain penguatan identitas bangsa. Oleh karena itu, perlu dipastikan bahwa bangunan bersejarah itu memiliki nilai identitas karena jika tidak akan menjadi masalah di kemudian hari, terutama dalam pelestariannya.

Setelah identitas, kriteria penting kedua dalam revitalisasi 
bangunan cagar budaya adalah nilai penting dengan nilai bobot sebesar 40,80\%. Besar bobot nilai penting yang cukup tinggi atau mendekati nilai bobot identitas (47,80\%), menunjukkan bahwa nilai penting memiliki pengaruh besar dalam revitalisasi bangunan cagar budaya. Hal ini disebabkan nilai penting merupakan salah satu yang menjadi dasar atau rambu-rambu dalam melakukan pelestarian cagar budaya yang di dalamnya terdapat pengembangan cagar budaya.

Dalam konsep revitalisasi bangunan cagar budaya GNI, nilai penting kriteria masih berada di bawah kriteria identitas. Hal ini menunjukkan bahwa nilai penting bangunan cagar budaya GNI dinilai masih belum cukup memiliki nilai identitas yang kuat bagi bangsa. Tentunya hal ini dapat mengurangi intensitas kepedulian terhadap pelestarian cagar budaya. Ini terbukti dengan adanya upaya untuk melakukan demolisi bangunan bersejarah yang masih dalam satu konteks dengan bangunan cagar budaya. Oleh sebab itu, perlu adanya penulisan nilai penting kembali untuk mengungkap dan memperdalam informasi mengenai nilai-nilai budaya pada bangunan cagar budaya untuk memperkuat identitas bangsa, kemudian diinterpretasikan sebagai nilai penting bangunan cagar budaya dalam konteks saat ini. Kriteria penting terakhir dalam evaluasi konsep revitalisasi bangunan cagar budaya GNI adalah nilai otentisitas dengan bobot sebesar $11,40 \%$. Besarnya selisih bobot nilai otentisitas dengan kedua kriteria sebelumnya disebabkan nilai otentisitas merupakan nilai yang dapat mengikuti atau dipengaruhi oleh nilai penting dan nilai identitas bangunan. Oleh sebab itu, nilai otentisitas adalah nilai turunan dari nilai penting bangunan cagar budaya dengan adanya perubahan-perubahan yang dialami bangunan tersebut. Apakah perubahan-perubahan tersebut diterima sebagai tambahan yang memiliki nilai penting atau tidak, bergantung bagaimana kita memaknai bangunan tersebut sebagai sebuah identitas.

\section{Hasil Pembobotan dalam Kriteria Utama Kriteria Identitas}

Berdasarkan hasil wawancara, nilai identitas dalam konsep revitalisasi bangunan cagar budya GNI menunjukkan bahwa konsep ini telah memunculkan konsep identitas bagi

\section{Model Name: Konsep Revitalisasi Bangunan Cagar Budaya Dalam} Kriteria Identitas

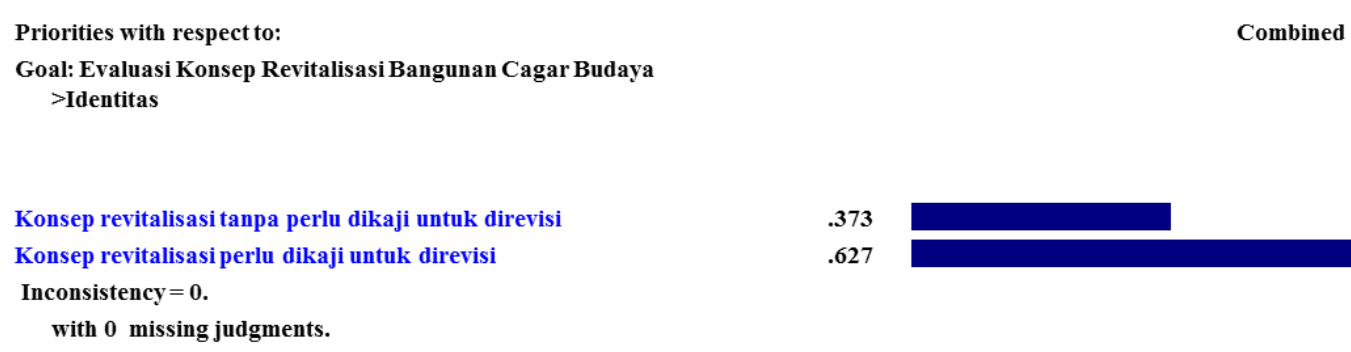

Gambar 5. Hasil pembobotan AHP dalam Kriteria Identitas (Sumber: Jarot Mahendra, 2018) 
perkembangan kebudayaan masyarakat saat ini sebagai living identity dan bagi penguatan pembentukan pusat kebudayaan nasional sebagai designed identity.

Namun, kedua identitas ini masih dianggap belum cukup kuat direpresentasikan dalam konsep revitalisasi ini. Hal ini terlihat dalam analisis AHP yang memberikan hasil sebagaimana terlihat pada Gambar 5. Dari hasil analisis AHP tersebut terlihat bahwa perlu dilakukan kajian kembali pada konsep revitalisasi ini dengan persentase $\quad 62,70 \%$. Hasil ini menggambarkan bahwa nilai identitas yang dimunculkan oleh konsep revitalisasi tidak cukup kuat untuk memberikan pengaruh bagi identitas bangsa.

\section{Kriteria Nilai Penting}

Dalam perumusan sayembara konsep pengembangan kompleks GNI, perumus sayembara pengembangan GNI yang bekerja sama dengan pemangku kepentingan lainnya telah menetapkan bahwa hanya kedua bangunan cagar budaya yang harus dipertahankan.

Penetapan bahwa hanya
bangunan cagar budaya yang
dipertahankan dalam pengembangan

kompleks GNI memang telah berdasarkan hasil kajian yang dilakukan lembaga pelestarian cagar budaya terkait, tetapi seharusnya perlu dilakukan kajian kembali terhadap nilainilai penting bangunan lain yang telah memenuhi salah satu kriteria bangunan cagar budaya berdasarkan UU No 11/2010. Kriteria yang dimasksud adalah bangunan yang telah berusia lima puluh tahun atau lebih. Karena dapat saja bangunan-bangunan yang telah berusia lima puluh tahun atau lebih saat ini memiliki nilai penting yang sebelumnya belum terlihat dalam kajian. Terlebih kajian yang dilakukan untuk penetapan bangunan-bangunan cagar budaya yang masih menggunakan UU No 5/1992 sebagai dasar penetapannya, masih dilakukan dengan sederhana.

Oleh sebab itu, sebelum perumusan sayembara konsep pengembangan GNI, perlu dilakukan kajian ulang mengenai nilai-nilai penting bangunan yang tidak hanya terfokus pada bangunan cagar budaya yang telah ditetapkan, tetapi juga pada bangunan lain yang telah berusia lima puluh tahun atau lebih. Hal ini penting untuk menghindari adanya perusakan bangunan yang memiliki nilai sejarah bagi bangsa Indonesia.

Model Name: KONSEP REVITALISASI BANGUNAN CB DALAM

KRITERIA NILAI PENTING

Priorities with respect to:

Combined

Goal: Tinjauan Konsep Revitalisasi Bangunan Cagar Budya

$>$ Nilai Penting

Konsep revitalisasi tanpa perlu dikaji untuk direvisi

Konsep revitalisasi perlu dikaji untuk direvisi

.468

.532

with 0 missing judgments.

Inconsistency $=\mathbf{0}$.

Gambar 6. Hasil Pembobotan AHP dalam Kriteria Nilai Penting (Sumber: Jarot Mahendra, 2018) 
Hasil analisis model AHP dalam kriteria nilai penting (Gambar 6), menunjukkan bahwa konsep revitalisasi bangunan cagar budaya GNI memberikan dampak terhadap penurunan nilai penting bangunan cagar budaya pada kompleks ini. Penurunan ini berakibat dikehendakinya konsep revitalisasi yang perlu dikaji untuk direvisi dengan bobot sebesar 53,20\%.

\section{Otentisitas}

Konsep otentisitas berfungsi sebagai pemancar terhadap nilai-nilai cagar budaya dalam kegiatan konservasi untuk mengevaluasi, melestarikan, dan mengelola cagar budaya dalam pengembangan lansekap budaya. Dalam konsep otentisitas perlu dipertimbangkan aspek tangible dan intangible dalam cagar budaya. Untuk itu, perlu diketahui aspek tangible dan intangible dalam cagar budaya, kemudian disepakati aspek apa yang harus tetap dipertahankan dan aspek yang dapat menerima intervensi fisik sebagai bentuk adaptasi bangunan cagar budaya.

Otentisitas bangunan cagar budaya di GNI dalam penulisan ini difokuskan pada bangunan utama (Gedung A) GNI karena bangunan ini telah mengalami perubahan-perubahan berupa adaptasi bangunan sebagai sebuah proses budaya. Proses budaya ini terjadi karena adanya kebutuhan ruang yang disebabkan oleh perubahan fungsi bangunan. Dalam proses budaya yang dialami bangunan utama, GNI masih dapat mencirikan bentuk asli bangunan. Bentuk asli pada bangunan ini dapat berfungsi sebagai otentisitas bangunan cagar budaya, khususnya otentisitas dalam aspek tangible.

Menurut the Nara Document on Authenticity (1994), otentisitas bangunan cagar budaya mencakup beberapa aspek. Namun, secara garis besar aspek-aspek ini dapat digolongkan ke dalam dua aspek besar, yaitu aspek tangible dan intangible (Diversity \& Diversity, 1994). Aspek tangible mencakup aspek bentuk dan desain arsitektur; substansi dan metarial; lokasi dan setting, sedangkan aspek intangible mencakup aspek pemanfaatan dan fungsi; tradisi dan teknik; spirit dan feeling.

Dalam konsep revitalisasi bangunan cagar budaya GNI, terdapat rencana pengembalian fasad bangunan Gedung A GNI ke masa awal pembangunannya setelah mengalami perubahan sebagai proses budaya. Padahal, pandangan ini dianggap belum tentu memiliki nilai otentisitas. Perubahan fasad Gedung A merupakan sebuah proses budaya yang terjadi seiring kebutuhan terhadap fungsi ruang. Proses budaya ini terjadi disebabkan bangunan cagar budaya memiliki penghuni yang dapat juga menetapkan perkembangan nilai penting bangunan dan otentisitasnya. Pada beberapa bangunan cagar budaya dapat saja bangunan dikembalikan seperti kondisi ketika bangunan itu memiliki nilai yang dianggap penting dan menjadi dasar penetapannya. Misalnya Gedung Perumusan Naskah Proklamasi yang bangunannya dibekukan atau dihentikan proses budayanya pada saat terjadinya peristiwa perumusan naskah proklamasi 
kemerdekaan Indonesia. Namun, Gedung A GNI memiliki karakteristik yang berbeda dengan Gedung Perumusan Naskah Proklamasi karena Gedung A GNI tidak mengalami suatu peristiwa yang memiliki nilai penting, seperti pada Gedung Perumusan Naskah Proklamasi.

Pandangan mengenai otentisitas ini memberikan pengaruh terhadap hasil analisis AHP dalam kriteria nilai otentisitas (Gambar 7). memberikan dampak pada pelestarian bangunan-bangunan yang ada di dalamnya. Konsep revitalisasi ini hanya terfokus pada aspek tangible bangunanbangunan di kompleks tanpa mempertimbangkan aspek intangible bangunan yang berupa nilai-nilai yang terkadung di dalamnya. Nilai penting bangunan sebagai sekolah yang berperan dalam mencerdaskan anakanak Indonesia seolah-olah diabaikan dengan menghilangkan bangunan

Model Name: Konsep Revitalisasi Bangunan Cb Dalam

Kriteria Otentisitas

Priorities with respect to:

Goal: Tinjauan Konsep Revitalisasi Bangunan Cagar Budaya >Otentisitas

Konsep revitalisasi tanpa perlu dikaji untuk direvisi

Konsep revitalisasi perlu dikaji untuk direvisi

.386

Inconsistency $=\mathbf{0}$.

with 0 missing judgments.

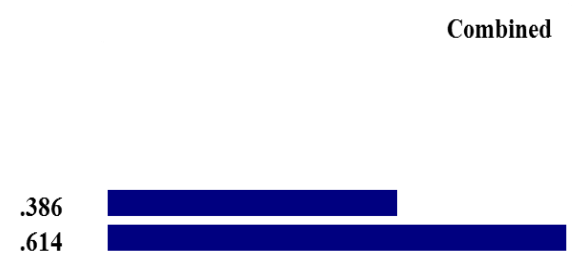

Gambar 7. Hasil Pembobotan AHP dalam Kriteria Nilai Otentisitas (Sumber: Jarot Mahendra, 2018)

Pada Gambar 7 terlihat bahwa rencana pengembalian fasad Gedung A ke fasad saat memiliki fungsi rumah tinggal tidak mendapatkan respons yang positif karena $61,40 \%$ hasil pembobotan AHP menginginkan konsep ini ditinjau kembali. Selanjutnya, ketika dikonfirmasi berdasarkan data kualitatif, bahwa pengembalian fasad Gedung A dapat mengurangi nilai penting bangunan sehingga proses budaya yang telah dialami oleh Gedung A merupakan salah satu bagian dari nilai penting bangunan tersebut.

\section{Hasil Evaluasi Konsep Revitalisasi Bangunan Cagar Budaya GNI}

Revitalisasi bangunan cagar budaya pada Gedung GNI dinilai dapat bersejarah, yaitu Gedung B GNI. Nilai otentisitas bangunan cagar budaya sebagai elemen-elemen yang melekat pada bangunan cagar budaya juga diabaikan dengan rencana intervensi fasad Gedung A GNI. Nilai identitas yang terbentuk dalam konsep ini masih dapat terwujud dengan tetap mempertahankan bangunan-bangunan bersejarah yang dinilai penting untuk dipertahankan. Oleh sebab itu, konsep revitalisasi bangunan cagar budaya di GNI perlu untuk direvisi agar aspek intangible bangunan CB tetap lestari.

Hal ini pun diperkuat dalam data kuantitatif hasil analisis AHP (Gambar 8). Analisis AHP memberikan hasil evaluasi konsep revitalisasi bangunan cagar budaya GNI untuk 
direvisi dengan bobot 59\%. Hasil ini menggambarkan bahwa expert memberikan pandangan konsep revitalisasi bangunan cagar budaya GNI berpotensi menurunkan aspek nilai penting bangunan, identitas, dan otentisitas.

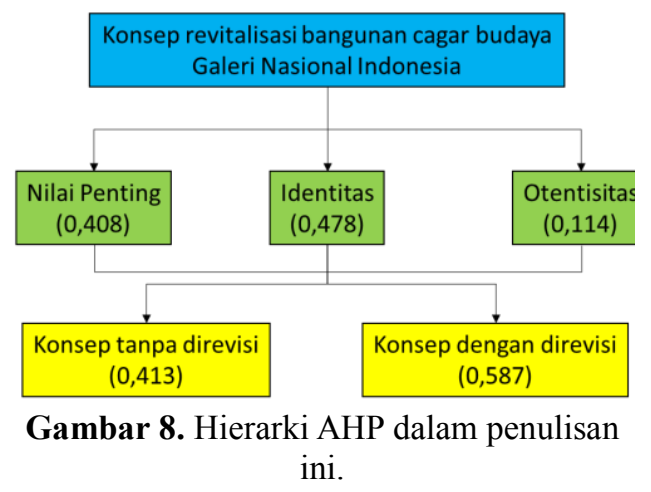

\section{SIMPULAN}

Hasil analisis AHP dalam evaluasi konsep revitalisasi bangunan cagar budaya GNI memberikan menyatakan bahwa identitas memiliki nilai bobot tertinggi dalam melakukan interpretasi bangunan cagar budaya, disusul tema nilai penting bangunan, dan terakhir nilai tema otentisitas pada bangunan cagar budaya. Hasil ini memberikan gambaran bahwa tema identitas memiliki pengaruh terbesar untuk meningkatkan kepedulian pemangku kepentingan terhadap pelestarian bangunan cagar budaya, khususnya di GNI. Selanjutnya, kriteria nilai penting berada pada peringkat kedua. Hal ini disebabkan nilai penting bangunan yang dimunculkan kurang memiliki nilai identitas yang kuat sehingga sikap dalam kebijakan pelestarian cagar budaya GNI kurang menunjukkan rasa memiliki (sense of belonging) terhadap bangunan yang berada dalam kompleks GNI. Oleh karena itu, nilai penting bangunan harus memuat nilai identitas. Terakhir adalah tema otentisitas; nilai otentisitas merupakan turunan dari nilai identitas dan nilai penting sehingga nilai otentisitas dipengaruhi oleh kedua nilai tersebut.

Analisis AHP secara keseluruhan menunjukkan bawah konsep revitalisasi bangunan CB di GNI yang tertuang dalam master plan pengembangan gedung GNI diusulkan untuk direvisi.

\section{DAFTAR PUSTAKA}

Brodjonegoro, B. P. (1992). AHP. Jakarta: Pusat Antar Universitas Studi Ekonomi Universitas Indonesia.

Danisworo, M. (2012). Revitalisasi di Tinjau dari Berbagai Sudut Pandang, 1-12.

Diversity, C., \& Diversity, H. (1994). THE NARA DOCUMENT ON AUTHENTICITY ( 1994 ), 46-48.

Gigliarelli, E., Cessari, L., \& Cerqua, A. (2011). Application of the Analytic Hierarchy Process (Ahp) for Energetic Rehabilitation of Historical Buildings. International Symposium on the Analytic Hierarchy Process.

Gospodini, A. (n.d.). European cities and place-identity, 8(March 2002), 19-36.

Kaymaz, I. (2013). Urban Landscapes and Identity. https://doi.org/http://dx.doi.org/10.5772/55754

Morano, P., Tajani, F., \& Locurcio, M. (2016). Cultural Heritage Valorization: An Aplication of AHP for the Choice of the Highest and Best Use, 223, 952-959. https://doi.org/10.1016/j.sbspro.2016.05.328 
Mulyono, S. (2007). Riset Operasi Edisi Revisi. Jakarta: Lembaga Penerbit Fakultas Ekonomi Universitas Indonesia.

Sjarief, R. (2010). Bunga Rampai Galeri Nasional Indonesia. Jakarta.

The Hong Kong Institute of Architect. (2012). Hong Kong Today: Conservation \& Revitalization of Historic Buildings. Teacher Notes.

Undang-undang Nomor 11 Tahun 2010, Pub. L. No. 11.

Yaolin, Z. (2006). An Application of the AHP in Cultural Heritage Conservation Strategy for China 1, 2(3), 16-20. 
PURBAWIDYA: $\square$ Vol 7, No.2, November 2018 149-166 